\title{
Female Family-Head Resilience in Building Family Food Security in New Normal Adaptation of Covid-19 Pandemic
}

\author{
INDRA KERTATI \\ Department of Public Administration, Faculty of Social and Political Sciences, \\ Universitas 17 Agustus 1945 (Untag) Semarang \\ Bendan Duwur Kecamatan Gajahmungkur Semarang Central Java \\ INDONESIA
}

\begin{abstract}
The problem in this research is that women access of providing food is limited due to Covid-19 pandemic, insufficient skills and education as well as poverty. The aim is to describe and analyze the capacity of poor women as family head in strengthening food security in the new normal period. The focus of this research is the family head of poor women in the city of Surakarta, Central Java, Indonesia. The results showed that the resilience of poor women's household heads was hindered by the legal identity they did not have after divorcing from their husbands. A legal identity will provide a foundation for women to access closed opportunities, because poor women do not understand legal identity is a prerequisite for accessing assistance in poverty alleviation programs. Fortunately, these poor women head of households have excellent resilience to maintain food security for their families. Their resilience is currently heavier than the monetary crisis in 19891999, because at this time they have to compete with others who are more knowledgeable in information technology. As the recommendations, the results of this study are aimed at the city government of Surakarta to develop a different affirmative strategy to strengthen family food security, especially for poor female household heads.
\end{abstract}

Key-Words: - women, poverty, resilience, covid-19, new normal, food security

Received: February 2, 2021. Revised: July 6, 2021. Accepted: July 13, 2021. Published: July 26, 2021.

\section{Introduction}

The Covid-19 pandemic is not over. Data on growth, collapse and development continue to be monitored by the Covid Task Force around the world. It is recorded that the distribution map for the last 14 days of October 2020 has reached 45.9 million cases with 1.19 million deaths. Indonesia has 410,088 confirmed cases, of which 58,418 are categorized as active cases or 14.2 percent of confirmed cases. A total of 337,801 were declared cured or 82.4 percent of confirmed deaths and 13,869 or 3.4 percent of confirmed deaths. Central Java Province, including the red area number 4 in Indonesia. The total confirmed as of the end of October was 35,126 with 3,955 suspects, 3,784 patients treated, 28,741 recovered and 2061 deaths. Covid-19 seems to never disappear, at least the predictions of scientists, University of Minnesota scientists reveal three models [1]. The first scenario is a series of repeated small waves known as peaks and valleys, followed by the second scenario known as a fall peak, which is the worst-case scenario occurring in the northern hemisphere in the fall of September to December 2020, which is considered to be similar to the Spanish flu that occurred 1918-
1919 as more and more people are infected without symptoms [2]. The third scenario is a slow burn or slow decline. This third scenario by Dr. Jeremy Greene from Johns Hopkins University is referred to as a social perspective, namely that the end of Covid-19 is not the loss of the virus, but rather boredom due to constant pressure from various sides, and wants to try to live side by side with Covid-19.

The impact of Covid-19 that is felt by the whole world is not only a health problem but also felt by the community is economic vulnerability, especially the poor and marginalized groups. The prediction of a study showed that the poverty rate will increase due to Covid-19 and result in a decline in national economic growth [3]. Statistics Indonesia (Badan Pusat Statistik/BPS) records in March 2020 amounted to 9.78 percent of the poor, an increase of 0.56 percentage points compared to September 2019 and an increase of 0.37 percentage points compared to March 2019. It is estimated that the worst affected are the poor, including those who are right in the poverty line and slightly above the poverty line. Based on the results of the BPS social demographic survey, low-income or low-income 
groups, 70 percent claimed to have experienced a decrease in income when Covid-19 hit the country [4]. This condition has given birth to various affirmative programs for affected poor groups such as direct assistance for the poor or cash assistance for Micro, Small \& Medium Enterprises (MSME) actors. This effort will act as a trigger so that people's purchasing power will increase and will encourage economic growth. The government realizes that the Covid-19 pandemic is different from other pandemics. As well as being fast, the pandemic has destroyed the national economies and economically weak communities [5].

The economic downturn of the lower class society is very different from the economic crisis in 1998. The crisis that occurred at that time was able to make MSMEs the backbone and buffer zone that saved the nation's economy although it had not significantly boosted national economic growth. After the crisis in 1997-1998 the number of MSMEs did not experience a reduction but increased, it was recorded that in 1997 there were 39,765,110, decreased in 1998 by 7.42 percent but in 1999 it increased 2.98 percent to $37,911,723$ and grew rapidly in 2000 to 4.94 percent or $39,784,036$ MSMEs [6]. The World Trade Organization (WTO) estimates that the volume of world trade globally is likely to decline by around 32 percent by 2020 during the Covid-19 period. Restrictions on community activities as an effort to deal with the Covid-19 pandemic have caused significant economic losses nationally. Some of the sectors that have slumped are the transportation, tourism, trade and household sectors. MSMEs generate employment between 50-95 percent, and contribute between 30-50 percent of Gross Domestic Product/GDP [7]. Women have special problems that are different from men. Covid-19 is equally hard hit, but women have an extra burden that men don't have. During the Pandemic, women not only have to maintain the health and safety of children and their families, but include greater care than normal times. Women have a double burden, namely domestic and public burdens. Domestic burdens are household burdens that are often mistakenly assumed to be natural, when in fact only social constructions are considered right but wrong. In the poor group, the domestic burden increases with the public burden, namely making a living, either additional or main income [8].

In the vulnerable group, namely women as the head of the family, like it or not, they have to run the two poles of the domestic and the public in an attractive manner $[9,10]$. Strengthening and maintaining the availability of adequate food is an option that cannot be refused. Meanwhile, the assistance that is expected to ease the burden has not been able to be accessed. They are vulnerable due to several reasons, among others, the legal identity as the head of the family cannot be owned due to divorce which is not registered in the civil registry or in the Religious Courts. On the other hand, female households must have a family card identity so that the right to government assistance can be enjoyed. A new habitual adaptation policy has been launched, with the hope that there will be public awareness that this unstoppable pandemic will be able to be adapted to good health protocols, as well as to fulfill calls for maintaining distance and contact with other people. This is not a simple matter. The social fatigue caused by the pandemic has stretched the gap in the economic sector. Office workers have better work stability, while smallscale economic actors have to struggle because the era of new adaptation changes has not been able to be broken through to strengthen the household economy. Resilience is weakened, because it has to compete with a new, increasingly stronger level, namely consumption based on information technology [11-13]. This insistent helplessness results in a prolonged vulnerability. Observing the phenomenon as mentioned above, the researchers conducted an analysis of the ability of poor women to maintain the safety, availability and quality of food for their families. The purpose of this study is to describe and analyze female heads of household in building food security in the adaptation period for new changes. The focus of this research is in the city of Surakarta because the female heads of household in the city of Surakarta are women who have resilience and resilience that has been tested in several disasters that have hit this city.

\section{Problems}

Women as the head of the family in building food security are not an easy problem. As women with the identity of the head of the family, it has been socially constructed that they are weak and helpless in facing the Covid-19 pandemic from various directions. This time the pandemic is considered a very heavy disaster. The heavy burden that is borne by the head of household of women, forcing them to get out of pressing situations that do not know when it will end. The era of adapting to new habits has long been launched. The community can carry out productive activities in strengthening the business network they are engaged in. This era is at stake whether the gap that has occurred can be minimized so that the optimum goal can be achieved. Most of 
the head of household for poor women in Surakarta City have micro to small businesses with various commodities moving forward to develop the resilience they have so far. The problem faced is that the construction on which to build a business is not as strong as during the economic crisis. The community has switched models in obtaining their needs, while micro and small entrepreneurs are still conventional in marketing their merchandise openly. It is this distortion that has not been understood by many that has triggered slow economic growth and weak breakout power. The problem that arises is how the ability to take small leaps in facing the era of adaptation to new habits so that family food security can be guaranteed both availability and quality.

\section{Research Methods}

This research is a descriptive qualitative type. The purpose of descriptive research is to describe a phenomenon and its characteristics. This research is more concerned with what than how or why something happened. Therefore, observation and survey tools are often used to collect data [14]. Qualitative research is more holistic and often involves rich data sets from multiple sources in order to gain a deeper understanding of individual participants, including their opinions, perspectives, and attitudes. Qualitative research often involves inductively exploring data to identify recurring themes, patterns, or concepts and then explaining and interpreting those categories [15].

In addition to describing the situation and condition of female family heads facing the Covid19 pandemic, this study also analyzes their resilience to strengthen family food security. The subject of this research is the head of household (of poor women in the City of Surakarta. The types of data used are primary data in the form of in-depth interviews with research subjects and secondary data in the form of special publications both from BPS and from relevant Regional Apparatus Organizations.

The subjects of this study were poor female head of household as seen from the Integrated Social Welfare Data (Data Terpadu Kesejahteraan Sosial/DTKS) with characteristics, namely female household heads with the lowest $40 \%$ welfare status. The number of research subjects was 61 poor women household heads. Data collection was done by in-depth interviews, namely conducting interviews with research subjects, exploring stories or cases and stories from the lives they lived. Completing in-depth interviews conducted observations of the activities of the research subjects. Data processing is done by means of triangulation which is based on the assumption of using several sources: data, methods and researchers that can neutralize the research bias inherent in one particular data source. The triangulation method offers overcoming the disadvantages of a single method. The use of qualitative descriptive makes it possible to use several different methods for the investigation of phenomena of interest and the results provide complementary confirmation, so that valid results are obtained [16].

\section{Results}

In the Indonesian dictionary, resilient means chewy, while resilience is the property of a material that returns to its original shape when it is stretched or when the supports are no longer working. Resilience is defined as reliance or something to be able to survive. The word resilience is often used in discussions of community capacity in dealing with environmental changes. Food safety according to Law No. 18 of 2012 concerning Food is a condition and effort required to prevent Food from the possibility of contamination of biological, chemical and other objects that can disturb, harm and endanger human health and does not conflict with religion, belief, and community culture so that it is safe for consumption. This law also defines food security and independence. Food independence is the ability of the state and nation to produce various kinds of food from within the country which can ensure the fulfillment of sufficient food needs at the individual level by utilizing the potential of natural, human, social, economic resources and local wisdom in a dignified manner. Law No. 18 of 2012 stated that food security is a condition for the fulfillment of food for the state to individuals, which is reflected in the availability of food that is sufficient, both in quantity and quality, safe, diverse, nutritious, equitable, and affordable and does not conflict with religion, belief, and community culture, to be able to live healthy, active and productive in a sustainable manner.

These three basic concepts are needed to understand food comprehensively. In terms of food independence, the availability of rice as the main consumption of the community becomes a commodity that plays a role in fulfilling people's livelihoods because of some considerations that are rice is the main source of carbohydrates for the majority of Indonesians and nearly 90 percent of the 
total population of Indonesia consumes rice; most of the livelihoods of the Indonesian people are farming so that the provision of rice fields whose job is the largest in the food crop sector; total expenditure 30 percent of poor households are used for rice consumption; and, in terms of health, the Recommended Dietary Allowances (RDA) of grains is 50 percent of the total energy consumption of the food group. Therefore, the availability of national rice depends on 3 aspects, namely: domestic rice production; procurement of rice reserves through Indonesian Bureau of Logistics (Badan Urusan Logistik/Bulog) and foreign rice procurement policies [17].

Food independence to maintain the continuity of domestic rice production, protect farmers so that the harvest is distributed, guarantee prices for farmers and easy access to rice in the community. According to Food and Agriculture Organization/FAO, Indonesia is among the third largest rice producing countries in the world after China and India. China's rice production amounted to 741 million tons, India's 153 million tons, while Indonesia's rice production was 75.6 million tons [18]. Taking into account this condition, the effort that must be made is rice self-sufficiency so that domestic needs do not depend on foreign products, namely [17]. From the supply side, it is conducted by encouraging increased domestic rice production by applying appropriate technology, while from the demand side, it is by promoting campaigns "one day no rice" through food diversification activities.

Sustainable food security is defined as when all people at all times have sufficient physical, social and economic access, safe and nutritious food that meets their dietary needs and food preferences, lives an active and healthy life without compromising the productive capacity of natural resources, the integrity of biological systems, or environmental quality. The 1996 Rome Declaration on Food Security and the World Food Summit Plan of Action recognize that although food availability has increased substantially over the past decade, serious constraints in access to food, coupled with the inability of households to buy food, instability of supply and demand and natural disasters and caused by humans, prevent many people from meeting their basic food needs [18]. In this context, the 1996 World Food Summit reaffirmed the importance of poverty alleviation through the full participation of women and men to achieve sustainable food security for all [19].

Government Regulation number 86 of 2019 concerning food safety states that the implementation of food safety is carried out through food sanitation, regulation of food additives, regulation of genetically modified food products, regulating food irradiation, stipulation of food packaging standards, providing food safety and quality assurance, and guarantee of halal products for those who are required. This government regulation mainly regulates the implementation of security in a broad sense, in large production processes to ensure food safety in a broad sense and not individually. The era of the Covid-19 pandemic, which has reached the stage of adapting to new habits, provides new challenges in the form of food security for the community. Food security is the ability to provide food that is affordable, cheap, and safe for families. This new challenge is not only for the government, but individually the community is required to be able to fulfill food security for the family.

The era of adapting to new habits is still being felt heavily by the community, especially women as heads of poor families. Poor women heads of families have to work extra hard because most of them are casual non-agricultural workers $(21.31 \%)$. While others are private laborers / employees $(16.39 \%)$ and $13.11 \%$ do not work as shown in Figure 1.

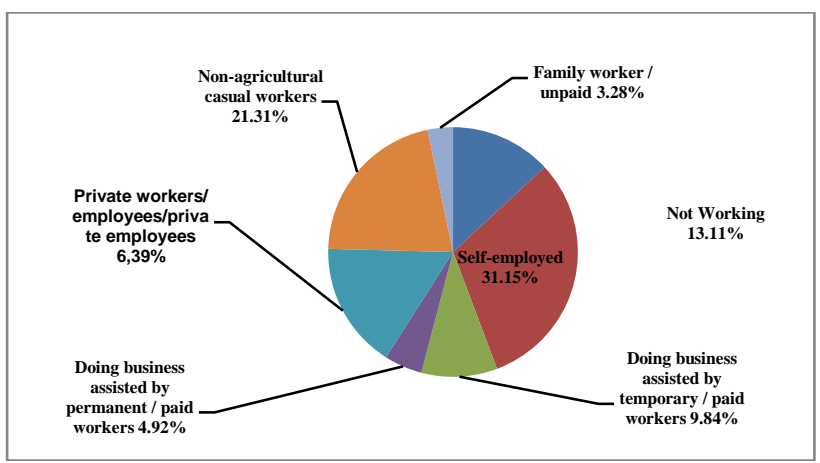

Fig.1: The Livelihoods of Poor Female Head of Families in Surakarta City

Source: Processed from primary data, 2020

Poor women as family head do get assistance from the government, but not all get it. There were 96.72 percent of poor female family head interviewed who received social assistance and 3.28 percent did not receive social assistance. The types of assistance obtained were Smart Indonesia Program amounting to 32.58 percent; Non-Cash Food Assistance (Bantuan Pangan Non Tunai/BPNT) amounting to 31.82 percent; and the Family Hope Program (Program Keluarga Harapan/PKH) by 28.03 percent. Receipt of this assistance does not overlap. They can get one or two of the help, but what they receive is not sufficient for their daily needs. 
Among the assistance received, rice for the poor (beras miskin/raskin) was the assistance that received many benefits, even though the amount received was not complete as recognized by $66.67 \%$ percent of poor women family head who received the amount of poor rice assistance (raskin) were less than the amount they should have, namely $15 \mathrm{~kg}$, only 33.33 percent stated that they received rice assistance for the poor (raskin) in accordance with the amount required. All types of assistance received are recognized as helping them in overcoming life's difficulties, even though they are admittedly not in accordance with their needs. Several poor female head of households admitted that they did not receive assistance due to the incomplete divorce process from their husbands. The divorce imposed by the husband, or the divorce suit filed was not formally followed and was registered at the Civil Registration Office or the Religious Court. This hanging legal identity status has fatal consequences because the documents held by women, who should have changed their residency status, cannot be fulfilled. Some of the reasons put forward were that the process of obtaining a divorce certificate was hampered by costs, and some admitted that they did not understand that divorce status had an impact on residency status. As is known, various poverty alleviation programs or covid-19 fast action programs are aimed at families. There are several programs aimed at individuals but with special conditions, for example assistance for MSMEs, or morning work assistance for workers who are registered as members of the Employees Social Security System (Badan Penyelenggaraan Jaminan Sosial/BPJS Ketenagakerjaan). This means that those who are not recorded will not get the assistance.

Most of the female family head recipients were not individual beneficiaries, they were among the target groups as the poor. The effort they have taken is by doing various businesses that are considered to have opportunities to make money. Some of the businesses they do are selling food, switching from their own business to laborers, selling vegetables at the market, transporting workers, washing workers, and making masks [20]. This effort was not completely successful, they made changes to their survival strategy over and over again with the various types of businesses they were engaged in. It is this ability to make changes that is amazing. They admit that the effort was made with great effort and very hard, because the competitors they face are not just fellow poor people but are competing with owners of large capital and wide access.
Great efforts have been made by poor women family head to strengthen family resilience, especially in terms of food. For them, food security is a priority, while other needs are second. They realize that food quality for families during the Covid-19 pandemic is very important. In the midst of their economic limitations, they tried hard to provide pagan families with the minimum standard they could afford. According to the acknowledgment of several family heads, the provision of family food has increased in quality. Before Covid-19 they ate what they were, the important thing was that they had rice and chili sauce available, now their diet has changed.

They try to comply with government recommendations, at least vegetables and vegetable protein are met, even if they provide animal protein, their ability is to provide eggs, salted fish, and chicken, especially broiler chickens with the head and legs. The average expenditure for providing family meals ranges from 20-30 thousand per day. Another priority that has been prepared is family health. They traditionally provide herbal medicine from the cheapest herb namely turmeric, lemongrass leaves and a little ginger. Some universities and NGOs distribute herb assistance to them, although it is limited, it can be used to support family health. However, not all of the recommendations are for the use of health protocols, namely using masks, followed. The reason it is difficult to breathe when working is a classic reason, but they still use masks if they are outside the home environment [21, 22].

The problem faced in providing quality food is the affordability to provide food in a sustainable manner. They are pessimistic that if the pandemic continues, the ability to provide food security for families will be threatened. The inability to compete is recognized as a formidable obstacle. Some people claim to have the ability to master information technology a little thanks to the help of their children, but most say that they do business based on business intuition that has been done so far. If you are unable to survive the business you are doing, then the alternative you will take is to become a laborer, or to invite your family to be involved in the business you are engaged in. Family food security is determined by the economic capacity of the household. The period of the Covid19 pandemic for poor women family head is an acrobatic period for the family's economy, namely the need for business capital as a basis for continuing the business that has been practiced so far. The problem of working capital is not simple. So far, capital support has been obtained from extended families and debts from neighbors or 
middlemen. This dependence gets squeezed even more when they are unable to get out of poverty. Some who get assistance from the government can breathe a little, but for those who do not get assistance, they depend on the helping hand of neighbors or distant families.

The kinship ties between neighbors and distant families are a lifeline for the truly poor and downtrodden. Even though they are worried about the assistance, whether they like it or not, it must be accepted. Those who get a helping hand from neighbors and distant relatives, as well as from social foundations, are those who are no longer able to survive. Another problem that must be faced is in terms of family care. It turns out that the provision of quality family food must be balanced with parenting styles which in this pandemic can no longer be fully fulfilled. Public and domestic spaces attract each other, which in the end, poor women family head must choose public space as a way to provide quality pagan. Childcare is completely left to older children, parents, relatives and neighbors. It is not surprising that domestic violence appears especially psychological violence due to the parenting style that is delegated. The findings of this study 3 out of 10 of them experienced violence.

\section{Discussion}

Understanding the findings above shows that food issues are closely related to gender status. Social phenomena are related to psychologically construct socially, in harmony with the culture that shapes gender identity and gender roles [23]. Gender roles that are potentially, culturally determined and / or stereotyped have increased vulnerability in both men and women [24-26]. Poor women and girls predominantly experience universal stereotypes including family management, physical and emotional care for others. This shows adherence in relations with society [27], and prioritizing the needs of others above one's own [28-31]. Such traditional roles can place women at greater risk of vulnerability, be it social, economic, cultural vulnerabilities including vulnerability to violence. Passive and submissive gender stereotypes of women in social relations create inequality and put women at risks that have been accepted. This shows that women have psychological resilience that is able to overcome the problems they face. Psychological resilience was significantly associated with life satisfaction and inversely related to psychological stress. The resilience factor encourages the emergence of a commitment to life and strengthens the welfare that is dreamed of in the family. The challenge factor contributes that a positive orientation to the future is a significant aspect. Adaptation to the losses resulting from divorce makes them come to terms with the demands, challenges including vulnerability as a significant life event [32].

Resilience is generally considered to describe the quality of being resilient [33], and applies to individuals who manage to achieve positive psychological outcomes despite facing serious negative life circumstances [34]. Resilience as the ability to adapt to changing environments or the ability to recover well after adversity, and is associated with personal attributes such as hardiness and resilience [35, 36]. Analysis of the concept of resilience identifies a number of defining attributes such as having a sense of self-determination, positive self-esteem, a sense of humor, and a positive relationship [36]. This term does not necessarily imply immunity to the ill effects of stressful living conditions but rather the ability to exhibit normal development under difficult conditions [37]. This is what happens to poor female head of households who have strong coping abilities in the midst of the many pressures that come to them. Resilience in the family refers to the characteristics, dimensions and properties of the family that help to be resilient in the face of change and adaptive in dealing with crisis situations. Resilience is generally understood to have two components, namely the ability to face risks or difficulties, and individuals or families succeed in making positive adaptations in facing challenges [37].

The research findings show the same thing, family support and social environment contributed to them getting out of the pandemic situation in the new normal era. Dependence on immediate family, such as daughters, is seen as a "helper," who must help with household activities. The bad impact is that the priority of helping the family has set aside the priority of education. Recent studies of women at the university level in Cameroon have also revealed that marital status, childbearing, family responsibilities, culture and traditions, financial autonomy, and participation in decision making contribute to poor performance in education [38]. These factors also contribute to high female dropout rates and make women less competitive in the labor market suffer marginalization and discrimination, due to their social status [39].

The various findings above require affirmative actions in the form of public policies and concrete actions to strengthen food security in the family. The ability of women with resilience even though 
they are not stable has contributed to the provision of safe family food. Referring to the results of similar research in Jambi Province, it turns out that socio-economic factors have a significant effect on food security [40]. The public policy model for women's domestic violence must be particularistic. The model built involves the social environment, and opens opportunities for female domestic workers without legal identity to get the same treatment. Meanwhile, real actions can be built in two perspectives, namely practical action and strategic action. Practical actions can be in the form of direct assistance that has never been obtained, such as sufficient rice assistance in one month, durable dry side dishes such as salted fish or salted egg, and capital assistance for them to get up and start doing business.

Strategic action can be in the form of assistance including special treatment in fulfilling legal identities which can be useful to open access to obtain needed resources. Poor women and family heads of household must be able to avoid violence based on gender, family and social, especially by marginalizing them to the level of vulnerability that cannot be helped. Steps to overcome food security in the new normal family can be taken by reviewing the status of households headed by women without legal identity. The experience in Brazil in 2009 provides new insights into the determinants of quality of life using measures of food insecurity that ignore the effects of poverty, age, income, education, residence, and gender status. Various indicators of household internal composition have a statistically significant and non-linear effect on food insecurity. Women's preferences in expenditure and consumption are likely to have a greater positive effect on the welfare of other household members. This Brazilian experience shows that even though women experience stressors such as being more intense than men, they have the ability to make their families better because they have high resilience in strengthening food security in the family [41].

\section{Conclusion}

The results showed that head of household poor women in the new normal era experience quite severe challenges in managing a household with adequate family food security guarantees. The squeezing condition of poverty has narrowed the social scope due to the limited accessibility of the inherent gender status of women. The completely limited condition shows an inability to overcome situations that require different strengths from the normal conditions before the Covid-19 pandemic.
Vulnerability experienced is not only poverty, but legal status as the head of the family has become a barrier to accessing other needed resources. Despite its various limitations, it turns out that poor women's head of household has good resilience socially and economically. This bouncy ability is influenced by several factors, namely the ability to face risks or difficulties, and individuals or families successfully make positive adaptations in facing challenges. Another factor from this research was found, namely the support of family, community and social environment which contributed to them getting out of the pandemic situation in the new normal era.

The government, local governments must affirm public policies specifically for women family head, which can be started from the mapping of poor women's heads of household so that interventions can be more specific. Building social participation in poor women in the family head environments can avoid marginalization and stereotypes and strengthen their empowerment. Encouraging NGOs, universities, social and private foundations and philanthropists to take practical and strategic actions. New normal must be understood as a different leap from the normal situation, therefore reviewing the status of households headed by women without legal identity as a prerequisite for receiving assistance is important.

\section{References:}

[1] Anwar F., "Kapan Corona Berakhir? Ini Prediksi Para Ahli," Detikhealth.com, 2020. Available: https://health.detik.com/beritadetikhealth/d-5069316/kapan-coronaberakhir-ini-prediksi-para-ahli

[2] Levashenko V., Rabcan J., Zaitseva E., "Reliability Evaluation of the Factors That Influenced COVID-19 Patients' Condition," Applied Sciences, vol. 11, no. 6, pp. 2589, 2021.

[3] Suryahadi A., Al-Izzati R., Suryadarma D., "The Impact of COVID-19 Outbreak on Poverty: An Estimation for Indonesia," Smeru.or.id, 2020. Available: https://smeru.or.id/en/content/impact-covid19-outbreak-poverty-estimation-indonesia.

[4] BPS, Persentase Penduduk Miskin Maret 2020 naik menjadi 9,78 persen, Jakarta: BPS, $2020 . \quad$ Available: https://www.bps.go.id/pressrelease/2020/07/ 15/1744/persentase-penduduk-miskinmaret-2020-naik-menjadi-9-78-persen.html.

[5] Rattanakul C., Lenbury, Y., "Model analysis and simulation on impacts of 
COVID-19 pandemic on the economy: a case study of Thailand's GDP and its lock down measures," International Journal of Biology and Biomedical Engineering, no. 14, pp. 180-190, 2020.

[6] BPS, Tabel Perkembangan UMKM pada Periode 1997-2013, Jakarta: BPS, 2016. Available:

https://www.bps.go.id/statictable/2014/01/3 0/1322/tabel-perkembangan-umkm-padaperiode-1997--2013.html.

[7] Sugiri D., "Menyelamatkan usaha mikro, kecil dan menengah dari dampak pandemi Covid-19," Fokus Bisnis: Media Pengkajian Manajemen dan Akuntansi, vol. 19, no. 1, pp. 76-86, 2020.

[8] Kansiime M. K., Tambo J. A., Mugambi I., Bundi M., Kara A., Owuor, C., "COVID-19 implications on household income and food security in Kenya and Uganda: Findings from a rapid assessment," World development, vol. 137, no. 105199, 2021.

[9] Pinilih S. A. G., "Gender specificity in democratic elections: International implementability as an exemplary for Indonesian political landscape," Academic

Journal of Interdisciplinary Studies, vol. 9, no. 3, pp. 194-200, 2020.

[10] Perez-Siguas R., Tenorio-Casaperalta A., Quispe-Mamani L., Paredes-Echeverria L., Matta-Solis H., Matta-Solis E., "Resilience During the COVID-19 Pandemic in Female Heads of Household Residing in a Marginal Population in Lima," Adv. Sci. Technol. Eng. Syst. J., vol. 6, no. 1, pp. 995-999, 2021.

[11] Duarte D., Walshaw C., Ramesh N., "A comparison of time-series predictions for healthcare emergency department indicators and the impact of COVID-19," Applied Sciences, vol. 11, no. 8, pp. 3561, 2021.

[12] Shorten C., Khoshgoftaar T. M., Furht B., Deep Learning applications for COVID-19. Journal of Big Data, vol. 8, no. 1, pp. 1-54, 2021.

[13] Alsaeed N. I., Alqaissi E. Y., Siddiqui M. A., "An Agent-based Simulation of the SIRD model of COVID-19 Spread," International Journal of Biology and Biomedical Engineering, vol.. 14, pp. 210217, 2020.

[14] Borg, W. R., \& Gall, M. D., Guide for Preparing a Thesis or Dissertation Proposal in Education. New York: Longman, 1989.
[15] Nassaji, H., "Qualitative and descriptive research: Data type versus data analysis," Language Teaching Research, vol. 19, no. 2, pp. 129-132, 2015.

[16] Yeasmin, S., \& Rahman, K. F., "Triangulation research method as the tool of social science research," BUP journal, vol. 1, no. 1) pp. 154-163, 2012.

[17] Kurnia, L. A., \& Iskandar, D. D., "Food independence determinant (Rice) in Supporting the Availability of National Rice," Jurnal Ekonomi Pembangunan, vol. 17, no. 1, pp. 55-72, 2019.

[18] FAO, Indonesia at a glance, FAO, 2015. Retrieved from http://www.fao.org/indonesia/fao-inindonesia/indonesia-at-a-glance/en/.

[19] Balakrishnan, R. "Rural women and food security in Asia and the Pacific: Prospects and paradoxes," Rap Publication, 30, FAO, 2005. Retrieved from http://www.fao.org/3/af348e/af348e.pdf.

[20] Sulistyawan, A.Y., \& Antonius, E.P., "Socio-legal perspective of gender justice in Covid-19 handling policy in Indonesia," International Journal of Criminology and Sociology, vol. 9, no. 2, pp. 1301-1305, 2020.

[21] Yusriyadi, \& Sulistyawan, A.Y., "Sociolegal perspective on renewing the law order in new normal situation of COVID-19 pandemic," Indian Journal of Forensic Medicine and Toxicology, vol. 14, no. 4, pp. 1714-1718, 2020.

[22] Hoesein, Z.A., Halim, P., \& Arifuddin, A., "State ethics as the basic of legal policy for handling of Covid-19 in Indonesia," International Journal of Criminology and Sociology, vol. 10, no. 1, pp. 244-248, 2021.

[23] Yunger, J. L., Carver, P. R., \& Perry, D. G., "Does gender identity influence children's psychological well-being?," Developmental psychology, vol. 40, no. 4, pp. 572, 2004.

[24] Dale, S. K., Cohen, M. H., Kelso, G. A., Cruise, R. C., Weber, K. M., Watson, C., ... \& Brody, L. R., "Resilience among women with HIV: Impact of silencing the self and socioeconomic factors," Sex roles, vol. 70, no. 5-6, pp. 221-231, 2014.

[25] Galdi, S., Maass, A., \& Cadinu, M., "Objectifying media: Their effect on gender role norms and sexual harassment of women," Psychology of Women Quarterly, vol. 38, no. 3, pp. 398-413, 2014. 
[26] Jewkes R., Morrell, R., "Gender and sexuality: emerging perspectives from the heterosexual epidemic in South Africa and implications for HIV risk and prevention," Journal of the International AIDS society, vol. 13, no. 1, pp. 1-11, 2010.

[27] Brody L. R., Stokes L. R., Dale S. K., Kelso G. A., Cruise R. C., Weber K. M., ... Cohen M. H., "Gender roles and mental health in women with and at risk for HIV," Psychology of women quarterly, vol. 38, no. 3, pp. 311-326, 2014.

[28] Jack D. C., Dill D., "The Silencing the Self Scale: Schemas of intimacy associated with depression in women," Psychology of women quarterly, vol. 16, no. 1, pp. 97-106, 1992.

[29] Jefferis T. C., Theron L. C., "Explanations of resilience in women and girls: How applicable to black South African girls," Women's studies international forum, vol. 69, pp. 195-211, 2018.

[30] Jordan M. I., "On statistics, computation and scalability," Bernoulli, vol. 19, no. 4, pp. 1378-1390, 2013.

[31] Prentice D. A., Carranza E., "What women and men should be, shouldn't be, are allowed to be, and don't have to be: The contents of prescriptive gender stereotypes," Psychology of women quarterly, vol. 26, no. 4, pp. 269-281, 2002.

[32] O'Rourke N., "Psychological resilience and the well-being of widowed women," Ageing International, vol. 29, no. 3, pp. 267-280, 2004.

[33] Dyer J. G., McGuinness T. M., "Resilience: Analysis of the concept," Archives of psychiatric nursing, vol. 10, no. 5, pp. 276282, 1996.

[34] Rutter M., "Implications of resilience concepts for scientific understanding. Annals of the New York Academy of Sciences, vol. 1094, no. 1, pp. 1-12, 2006.

[35] Olsson C. A., Bond L., Burns J. M., VellaBrodrick D. A., Sawyer S. M.., "Adolescent resilience: A concept analysis," Journal of adolescence, vol. 26, no. 1, pp. 1-11, 2003.

[36] Earvolino- Ramirez M., "Resilience: A concept analysis," Nursing forum, vol. 42, no. 2, pp. 73-82, 2007.

[37] Lennon S. L., Heaman M., "Factors associated with family resilience during pregnancy among inner-city women," Midwifery, vol. 31, no. 10, pp. 957-964, 2015.
[38] Yeba J. S., Meno M., "Socio-cultural factors affecting Gender inequality in higher education: the case of doctorate students in some Cameroonian universities," J educ Res Afr, vol. 7, pp. 178-200, 2015.

[39] Nkemnyi F. M., Fombu C. Y. N., Kwobenyi N. G., Mumbang C., "An Assessment of the Role of Women in Development and Poverty Alleviation in Cameroon," In I. Piot-Lepetit (Ed.), Cameroon in the $21^{\text {st }}$ Century: Challenges and Prospects. Volume 2: Environment and People, pp. 219-234. New York: Nova Science Publishers, Inc., 2017.

[40] Hardiani H., Junaidi J., Prihanto P. H., "Food Security of Urban Female-headed Households: Case in Jambi Province, Indonesia," Turkish Journal of AgricultureFood Science and Technology, vol. 6, no. 9, pp. 1229-1236, 2018.

[41] Felker-Kantor E., Wood C. H., "Femaleheaded households and food insecurity in Brazil," Food Security, vol. 4, no. 4, pp. 607-617, 2012.

Contribution of Individual Authors to the Creation of a Scientific Article (Ghostwriting Policy)

Indra Kertati is the sole author.

\section{Sources of Funding for Research Presented in a Scientific Article or Scientific Article Itself}

There is no funding received from third parties for this study.

\section{Creative Commons Attribution License 4.0 (Attribution 4.0 International, CC BY 4.0)}

This article is published under the terms of the Creative Commons Attribution License 4.0 https://creativecommons.org/licenses/by/4.0/deed.en US 